\title{
Activation Parameters for Dynamics of Lysozyme and $\alpha$-Lactalbumin Adsorption onto Silica Surface in Aqueous Medium
}

\author{
F. K. ONWU* and O. U. IGWE \\ Department of Chemistry, Michael Okpara University of Agriculture, Umudike, \\ P.M.B 7267, Umuahia, Abia State, Nigeria \\ frank4kalu2007@yahoo.com
}

Received 31 March 2014 / Accepted 21 April 2014

\begin{abstract}
The adsorption densities of lysozyme and $\alpha$-Lactalbumin from aqueous solutions onto silica surface have been studied as a function of time and temperature. Kinetic measurements were carried out to determine the rate of adsorption of the proteins on the surface at various temperatures. The rates of adsorption fitted into first-order kinetic equation with two kinetic rate constants, $\mathrm{k}_{1}$ and $\mathrm{k}_{2}$, indicating that two kinetic steps are involved in the adsorption process. $\mathrm{k}_{1}$ represents the initial binding or anchorage of the protein molecules at the active sites of the solid surface and $\mathrm{k}_{2}$ represents the denaturation and reorganization of the bound proteins at the surface. The activation energies $\Delta \mathrm{E}_{1}{ }^{*}$ and $\Delta \mathrm{E}_{2}{ }^{*}$ for the proteins adsorption were obtained from Arrhenius equation and are given (in kJ mol${ }^{-1}$ ) as $45.637,41.430$ and 17.942, 15.971 respectively for the adsorption of $\alpha$-lactalbumin and lysozyme onto the silica surface. $\Delta H_{1}^{*}$ and $\Delta H_{2}^{*}$ correspond to the enthalpy changes for the two kinetic steps with values (in $\mathrm{kJ} \mathrm{mol}^{-1}$ ) of 43.121, 38.836 and 15.427, 11.379 for adsorption of $\alpha$-lactalbumin and lysozyme onto the silica surface respectively. The change in entropy of activation $\left(\Delta \mathrm{S}_{1}{ }^{*}\right.$ and $\left.\Delta \mathrm{S}_{2}{ }^{*}\right)$ for the two kinetic steps with values (in $\mathrm{Jmol}^{-1} \mathrm{~K}^{-1}$ ) of $-114.422,-128.095$ and $-217.081,-229.183$ were obtained for adsorption onto the silica surface following the initial order. The negative $\Delta \mathrm{S}^{*}$ values thus signify that refolding as well as unfolding of the proteins at the interface is controlled mostly by the order-disorder parameter, $\Delta \mathrm{S}^{*}$, occurring in the activated state. Results further show that for $\mathrm{k}_{1}{ }^{*}$ step; $\Delta \mathrm{H}_{1}{ }^{*}>\mathrm{T} \Delta \mathrm{S}_{1}{ }^{*}$ and for $\mathrm{k}_{2}{ }^{*}$ step, $\mathrm{T}_{\Delta} \mathrm{S}_{2}{ }^{*}>\Delta \mathrm{H}_{2}{ }^{*}$, thus buttressing the fact that the second step is mostly entropy-controlled. The results generally show that $\alpha$-lactalbumin was slightly better adsorbed onto the silica surface as compared to the lysozyme.
\end{abstract}

Keywords: Adsorption, Biomolecules, $\alpha$-lactalbumin, Lysozyme, Silica, Proteins

\section{Introduction}

Protein adsorption is a very complex process, which is driven by different protein-surface forces, including van der Waals and hydrogen bonding, hydrophobic and electrostatic forces ${ }^{1}$. A number of dynamic steps are involved in protein adsorption and they include bond formation between proteins and surfaces, lateral diffusion on the surface and conformational 
changes or rearrangements of adsorbed proteins ${ }^{2}$. Removal of protein adsorption requires the annihilation of all these attractive forces between proteins and surface. Important parameters for protein adsorption are $\mathrm{pH}$, temperature, ionic strength, the properties of the protein and the surfaces and also the nature of the solvent ${ }^{3-5}$.

Adsorption of proteins occurs on different solid-liquid interfaces. In a number of cases, protein adsorption leads to unfavourable results such as surface-induced thrombosis due to adsorption of plasma-proteins ${ }^{6}$, fouling of membranes used in food and beverage processing ${ }^{7}$ and performance degradation in analytical protein liquid chromatography.

Proteins are polyelectrolytes and adsorption usually occurs because of the coulombic attractions between the negatively charged surfaces and the positive charges on the protein molecules ${ }^{8}$. On a hydrophilic solid surface, the electrostatic attraction between a charged surface and an oppositely charged protein molecules is often the driving force for adsorption from solution onto the solid surface ${ }^{9}$. The amount adsorbed may then be determined by a balance between this electrostatic attraction and the electrostatic repulsion within the adsorbed layer. On a hydrophilic surface, the attraction is usually between the surface and the hydrophilic fragments within the protein, which may be strong enough to dominate any electrostatic repulsion ${ }^{10}$.

A further driving force for protein adsorption is entropy changes associated with dehydration of the protein or a structural rearrangement of the protein ${ }^{11}$. Strong surface interactions may damage the native state of a protein molecule, and lead to a loss of its coherent structures, denaturation. The degree of such structural deformation on adsorption depends on the nature of the surface and the relative stability of the protein structure ${ }^{12}$.

In this work, two globular proteins, $\alpha$-lactalbumin and lysozyme were chosen. $\alpha$-lactalbumin is the second most abundant protein in whey and has been chosen to represent proteins in the diary products. $\alpha$-lactalbumin is a compact globular protein with the dimensions of $3.7 \mathrm{~nm} \times 3.2 \mathrm{~nm} \times 2.5 \mathrm{~nm}$. Its molar mass is about $14,200 \mathrm{~g} \mathrm{~mol}^{-1}$ and is an acidic protein with an isoelectric point $(\mathrm{pI})$ value of 4.3. Lysozyme (protein from chicken egg white) is also a globular protein of slightly ellipsoidal shape with dimensions of $4.5 \mathrm{~nm}$ $\times 3.0 \mathrm{~nm} \times 3.0 \mathrm{~nm}$. Its molar mass is approximately $14,600 \mathrm{~g} \mathrm{~mol}^{-1}$ and is a basic protein with an isoelectric point (pI) value of 11.1. Lysozyme was chosen because of its welldefined molecular dimensions in its native state and it's been extensively used in a variety of studies. Also, its high thermal stability originating in part from four disulphide bond is likely to prevent complete unfolding at a surface ${ }^{13}$. Lysozyme is relatively a stable protein (i.e., 'hard' protein) compared to $\alpha$-lactalbumin.

The adsorbent used is silicon dioxide $\left(\mathrm{SiO}_{2}\right)$ commonly called silica. Studies on the properties of silica has shown that in the presence of water, the surface of silica becomes hydrated to form silanol groups $(-\mathrm{SiOH})$. It is believed that the high reactivity of crystalline silica to biological macromolecules is due to the unique properties of these surface silanol groups. The first theory is that $-\mathrm{SiOH}$ groups are hydrogen donors, whereas most biological macromolecules contain lone pair electrons on oxygen or nitrogen that serve as hydrogen acceptors. The formation of hydrogen bonds would result in strong interaction between silica and biological membranes, resulting in possible adsorption onto surfaces. It then became clear that the surface chemistry of silica is determined by the surface hydroxyl groups and thus investigation of the structure and reactivity of these groups became a major source of interest in silica. A second theory is that the surface of silica is negatively charged. At pH 7.0 one in $30-\mathrm{SiOH}$ groups would be negatively charged $\left(-\mathrm{SiO}_{2}{ }^{-}\right)$. 
A third theory is that cleavage of silica crystal, as would occur in silica flour milling, rock drilling and sandblasting, results in the generation of $\mathrm{Si}$ and $\mathrm{SiO}$ radicals on the fracture planes which can induce its interaction with biological macromolecule.

\section{Experimental}

Pure crystalline lysozyme (protein from chicken egg white, grade 1, product No L-6876, molecular weight $14,600 \mathrm{~g} \mathrm{~mol}^{-1}$ ) used in the adsorption studies was obtained from Sigma Chemical Co. (USA). $\alpha$-Lactalbumin from Bovine milk was purchased from Sigma-Aldrich USA. Chromatographic grade silica particles (mesh size $200 \mu \mathrm{m}$ ) from Burgoyne Burbridges and Co. (India) MUMBAI, product No. 07079 and batch No. 21920 was used without any further purification. All inorganic salts used were BDH products of analytical grade. Double distilled water was used throughout the experimental work. Digital pH meter CEH 198127 used for the analysis is a product of Hanna instruments inc. Woonsocket, Rhode Island, USA. The meter measures to an accuracy of 0.1 and has an in-built automatic temperature control (ATC). It was standardized using standard buffer solutions (4.10, 7.10 and 9.18) according to specifications. Visible spectrophotometer, 722S spectrophotometer; No. SFZ 1506010514 was used for quantification of the proteins. The absorbance was taken and their concentrations determined from the calibration curve. Digital analytical weighing balance X21-0014 KERN $770-15,15402301$, made in Germany was used. The balance measures to accuracy of $0.0001 \mathrm{~g}$ and mechanical shaker, versal shaker, type: LE-203/1 from Hungary was used.

\section{Methods}

The chromatographic-grade silica particles were washed several times with distilled water to remove ionic impurities and then dried for $24 \mathrm{~h}$ at $250{ }^{\circ} \mathrm{C}$ before use. The specific surface area of the silica was determined using the method of adsorption of aqueous solution of paranitrophenol onto silica as reported by Gilles and Nakhwa, $1962^{14}$. One gram of the silica particles was placed in seven $50 \mathrm{~mL}$ conical flasks containing $10 \mathrm{~mL}$ of different standard paranitrophenol solutions. The flasks were shaken vigorously for $1 \mathrm{~h}$ at a temperature of $30{ }^{0} \mathrm{C}$ to attain equilibrium adsorption and allowed to settle. The supernatant liquid was decanted and centrifuged for $15 \mathrm{~min}$ at $3000 \mathrm{xg}$. A drop of ethanol was added to reduce the surface tension and this allowed the floating powders to sink. The absorbance of the supernatant liquid was measured at $400 \mathrm{~nm}$ and concentration of unadsorbed paranitrophenol obtained from the calibration curve. The specific surface area of the silica was $103.9 \mathrm{~m}^{2} \mathrm{~g}^{-1}$.

The $\alpha$-lactalbumin and lysozyme materials under test were dissolved in the buffer solutions ( $\mathrm{pHs} 4.3$ and 11.1) used to prepare the test solutions. Portions of these solutions were diluted with the same buffer to obtain seven standard solutions having concentrations between 0.2 and $1.4 \mathrm{~g} \mathrm{~L}^{-1}$. These concentrations were evenly spaced and were used for the preparation of the standard curve. The buffer solutions used for the test and standard solutions were also used as blanks. pHs 4.3 and 11.1, which are the isoelectric pHs of $\alpha$ lactalbumin and lysozyme ${ }^{1,8}$ were employed for the analysis and at this pHs, the net charge on the proteins was zero.

In the experiment, $0.4 \mathrm{~g}$ of the silica particles was added to $10 \mathrm{~mL}$ of standard protein solution at the pHs 4.3 and 11.0 and ionic strength 0.01 . The flasks were shaken on a mechanical versal shaker at different contact times 1-20 min. and at different temperatures of $25{ }^{\circ} \mathrm{C}, 30{ }^{\circ} \mathrm{C}$ and $35{ }^{\circ} \mathrm{C}$ at a speed of 6.0 oscillations per second. For the estimation of the equilibrium amounts, the flasks were shaken for $16 \mathrm{~h}$ and then kept undisturbed for another $4 \mathrm{~h}$. Equilibrium was attained and protein adsorption was completed during this period. 
At the end of this period, the concentration of the proteins in the bulk solutions was determined by spectrophotometer with the Lowry method ${ }^{15}$. The concentration of the proteins in the bulk solution was then read off from the calibration curve.

The quantification of the unadsorbed protein was carried out using the Lowry assay. To $1.0 \mathrm{~mL}$ of each test solution and the blank, $6.0 \mathrm{~mL}$ of alkaline copper reagent was added, mixed and allowed to stand at room temperature for $10 \mathrm{~min} .0 .5 \mathrm{~mL}$ of diluted FolinCiocalteu reagent was added, shaken and allowed to stand for another $30 \mathrm{~min}$. The absorbance of the test solution was determined at the maximum wavelength of $750 \mathrm{~nm}$ with a visible spectrophotometer, using the solution from the blank to set the instrument to zero absorbance.

Alkaline copper reagents used for the quantification of the concentration of the unadsorbed amount of protein were prepared by mixing the following reagents in equal proportions:

$\begin{array}{lc}\text { Copper sulphate } & 20 \mathrm{mg} \mathrm{L}^{-1} \\ \text { Sodium potassium tartarate }\left(\mathrm{NaKC}_{4} \mathrm{H}_{4} \mathrm{O}_{6} \cdot 4 \mathrm{H}_{2} \mathrm{O}\right) 20 \mathrm{mg} \mathrm{L}^{-1} \\ \begin{array}{lc}\text { Sodium hydroxide } & 40 \mathrm{mg} \mathrm{L}^{-1} \\ \text { Sodium carbonate } & 20 \mathrm{mg} \mathrm{L}^{-1}\end{array}\end{array}$

\section{Results and Discussion}

The adsorption of the proteins (lysozyme and $\alpha$-lactalbumin) onto the silica surface was fast taking place within twenty minutes.

The variation of adsorption capacity, $\mathrm{q}_{\mathrm{t}}(\mathrm{mg} / \mathrm{g})$ with time $\mathrm{t}$ in minutes during the nonequilibrium adsorption of the lysozyme by a definite amount $(0.4 \mathrm{~g})$ of adsorbents are shown in Figures 1 and 2. The ionic strength, $\mathrm{pH}$ and initial protein concentrations remained fixed during each set of the experiments. From Figures 1 and 2, it is noted that for the proteins at the initial stage of adsorption, the amount adsorbed $\left(\mathrm{q}_{\mathrm{t}}\right)$ increases sharply with time. This indicates that the rate of adsorption was very fast initially, but with the increase of the elapsed time its values became slower in magnitude and finally after $16 \mathrm{~h}$, the bulk concentration attains a constant value $\mathrm{C}_{\mathrm{e}}$ at the state of adsorption equilibrium. The experimental data was found to fit well into Lagergren first-order kinetic model given as ${ }^{16}$ :

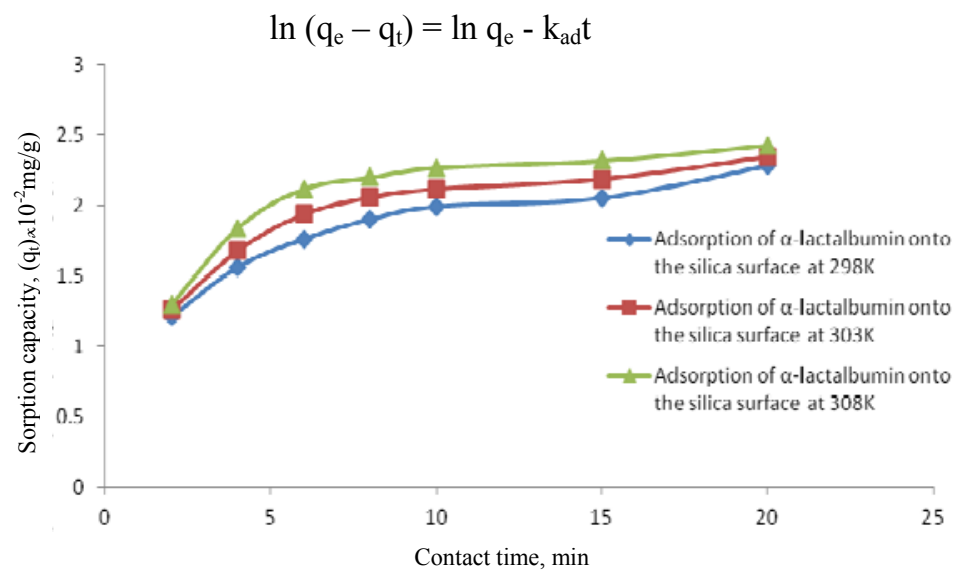

Figure 1. Variation of Sorption capacity, $q$ t against time, $t$ for the adsorption of $\alpha$-lactalbumin onto silica surface ( $\mathrm{pH} 4.3$, Initial conc. $1.0 \mathrm{mgL}^{-1}$ ) 


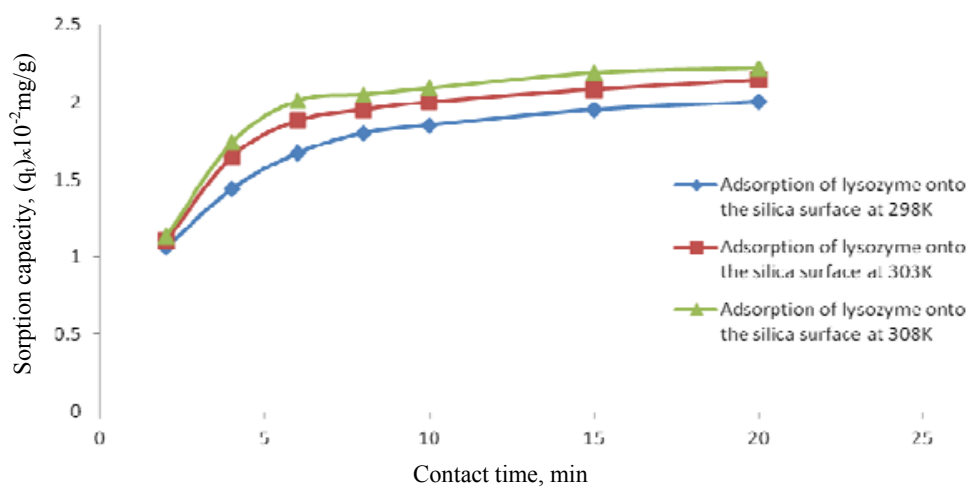

Figure 2. Variation of Sorption capacity, qt against time, $\mathrm{t}$ for the adsorption of lysozyme onto silica surface ( $\mathrm{pH} \mathrm{11,} \mathrm{Initial} \mathrm{conc.} 1.0 \mathrm{mg} \mathrm{L}^{-1}$ )

The plots of $\ln \left(\frac{q_{e}}{q_{e}-q_{t}}\right)$ versus time as given in Figures 3 and 4 indicate the existence of two linear portions with different slopes from which two kinetic rate constants $\mathrm{k}_{1}$ and $\mathrm{k}_{2}$ were obtained. The $k_{1}$ values were found to be greater than $k_{2}$ values. The values of $k_{1}$ show that the rate of adsorption increases with increase in temperature for adsorption onto the silica surface. The $\mathrm{k}_{2}$ values were not significantly affected by the change in temperature.

The existence of two kinetic rate constants further reveals that two major kinetic rate processes are involved in proteins adsorption. $\mathrm{k}_{1}$ corresponds to the initial binding or anchorage of protein molecules with the active sites/spots of the solid surface by removal and reorganization of surface bound water leading also to some required conformational unfolding of the bound protein molecules at the interface. $\mathrm{k}_{2}$ represents the denaturation and reorganization of the bound protein at the interface, leading to the formation of spread films as earlier reported by Sarka and Chattoraj, $1993^{17}$.

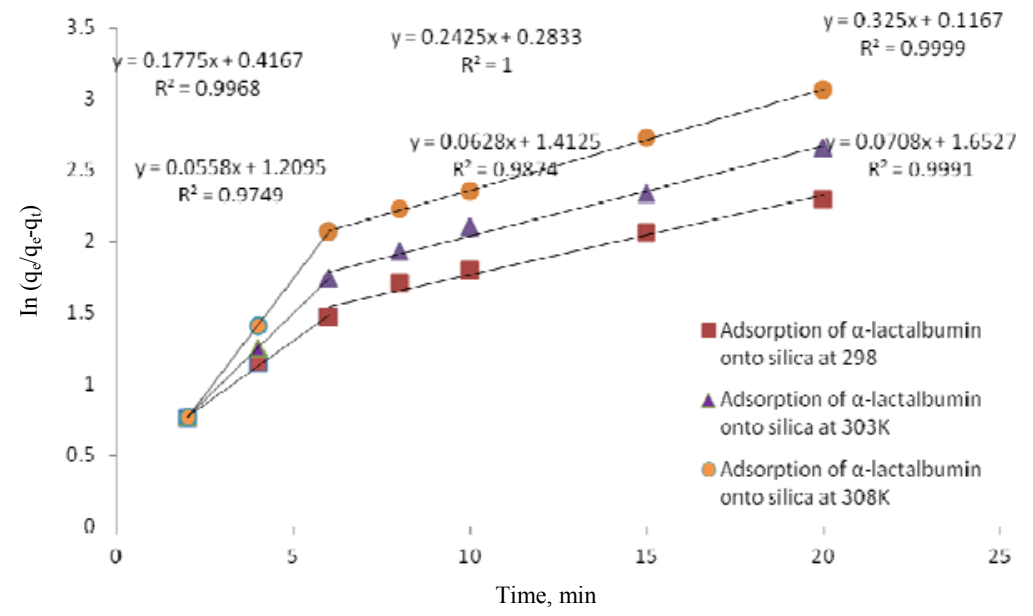

Figure 3. First-order plot of $\ln \left(\frac{q_{e}}{q_{e}-q_{t}}\right)$ against time for the adsorption of $\alpha$-lactalbumin onto silica at $\mathrm{pH} 4.3$, temperatures $293 \mathrm{~K}, 303 \mathrm{~K}$ and $313 \mathrm{~K}$ 


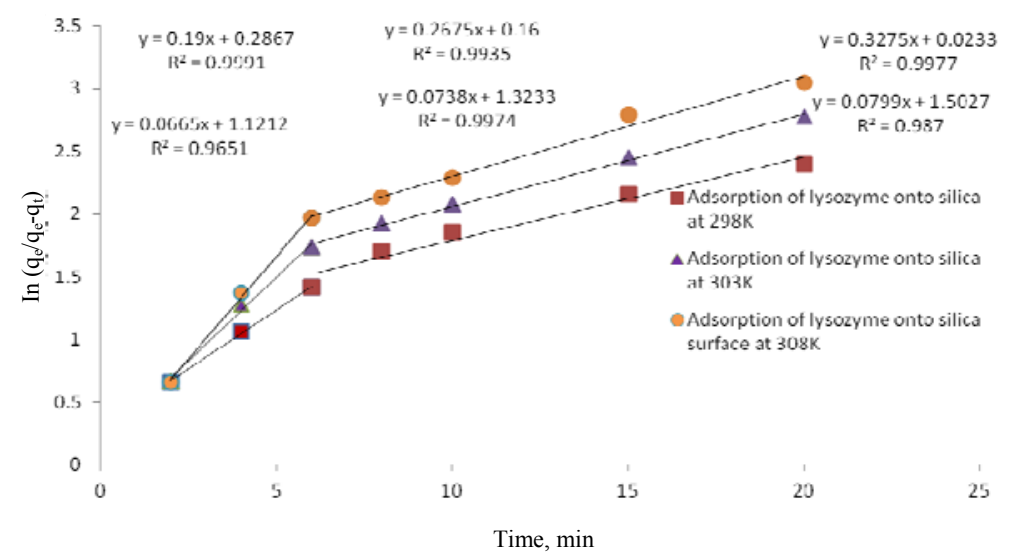

Figure 4. First-order plot of $\ln \left(\frac{q_{e}}{q_{e}-q_{t}}\right)$ against time for the adsorption of lysozyme onto silica surface at $\mathrm{pH} 11$, temperatures $293 \mathrm{~K}, 298 \mathrm{~K}$ and $303 \mathrm{~K}$

Previous studies have already stated that three steps are involved in protein adsorption onto solid surfaces. The first step in the kinetics of protein adsorption onto surfaces is the initial diffusional flow of the biopolymers onto the surfaces ${ }^{17,18}$. This diffusional flow is a very fast process and it is completed in all probability within a fraction of a second and is not regarded as a rate controlling step. The second step is the initial binding of protein molecules with the active sites of the solid surface while the last step involves the conformation of the bound protein at the interface. The first-order plots are displayed in Figures 3 and 4 below from which the kinetic rate constants were evaluated.

The activation parameters were evaluated from Plots of $\operatorname{Ink}_{1}{ }^{*}$ and $\operatorname{Ink}_{2}{ }^{*}$ against the reciprocal of $\mathrm{T}$ (the absolute temperature) and are shown in Figures 5 and 6 for both $\alpha$-lactalbumin and lysozyme onto the silica surface. These plots give straight lines, so that using the Arrhenius equation, the energies of activation $\Delta \mathrm{E}^{*}$ were calculated. The activation energy $\Delta \mathrm{E}_{1}{ }^{*}$, for this step calculated on the basis of Arrhenius equation varies between $45.637 \mathrm{~kJ} \mathrm{~mol}^{-1}$ and $41.430 \mathrm{~kJ} \mathrm{~mol}^{-1}$ and $\Delta \mathrm{E}^{*}{ }_{2}$ between $17.942 \mathrm{~kJ} \mathrm{~mol}^{-1}$ and $15.971 \mathrm{~kJ} \mathrm{~mol}^{-1}$ for both $\alpha$-lactalbumin and lysozyme onto the silica surface.

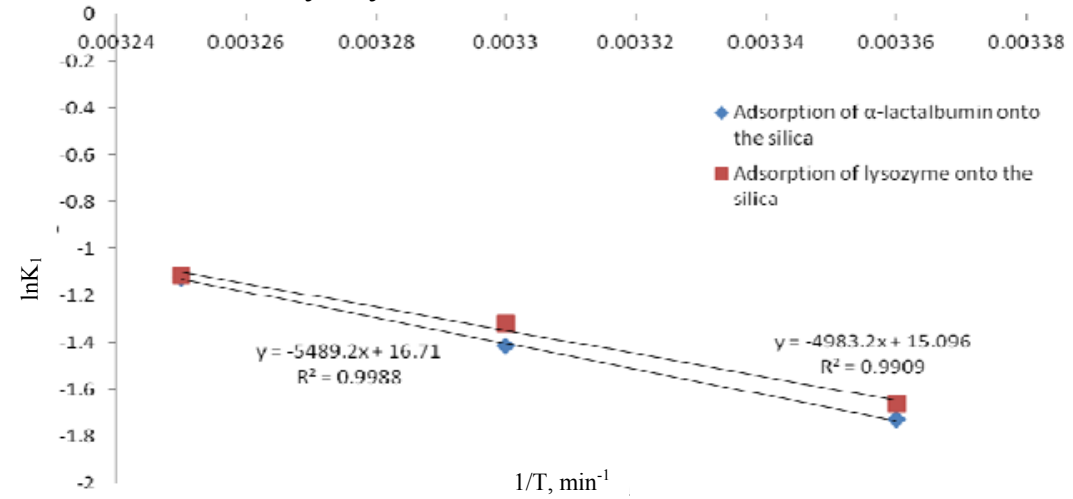

Figure 5. Plot of $\ln \mathrm{k}_{1}$ against $\mathrm{T}^{-1}$ for the adsorption of the proteins onto the silica surface following Arrhenius equation 


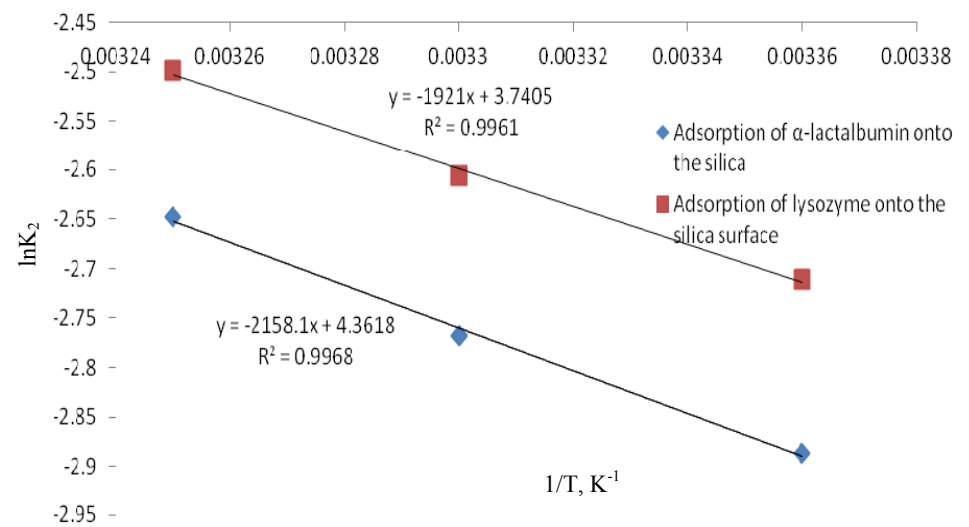

Figure 6. Plot of $\ln \mathrm{k}_{2}$ against $\mathrm{T}^{-1}$ for the adsorption of the proteins onto the silica surface following Arrhenius equation

Figures 7 and 8 display linear plots of $\mathrm{In}^{*} / \mathrm{T}$ against the reciprocal of absolute temperature $\mathrm{T}$ for the proteins adsorption following Eyring equation

$$
\ln \left[\frac{k^{*}}{T}\right]=\ln \left[\frac{k}{h}\right]+\frac{\Delta S^{*}}{R}-\frac{\Delta H^{*}}{R T}
$$

Where $\mathrm{k}$ and $\mathrm{h}$ are Boltzmann's and plank's constants respectively. The entropy of activation $\Delta \mathrm{S}^{*}$ and the enthalpy of activation $\Delta \mathrm{H}^{*}$ for this step were evaluated from the intercept and the slope of each linear plot.

It is noted from the values of $\Delta \mathrm{H}_{1}{ }^{*}$ and $\Delta \mathrm{H}_{2}{ }^{*}$ and $\Delta \mathrm{S}_{1}{ }^{*}$ and $\Delta \mathrm{S}_{2}{ }^{*}$, (Table 1) that for $\mathrm{k}_{1}$, $\Delta \mathrm{H}_{1} *>\mathrm{T} \Delta \mathrm{S}_{1} *$; which means that binding or anchorage of the proteins in the activated state is mostly an enthalpy-controlled process. It is also noted with considerable interest that $\Delta \mathrm{H}_{2}{ }^{*}$ obtained from the Eyring equation were lower than $\mathrm{T} \Delta \mathrm{S}_{2}{ }^{*}$, showing that the re-orientation step is mostly an entropy- controlled at the activated state. The entropy of activation $\Delta \mathrm{S}^{*}$ from Eyring equation is negative because two reactant species come together to form a surface compound ${ }^{19}$.

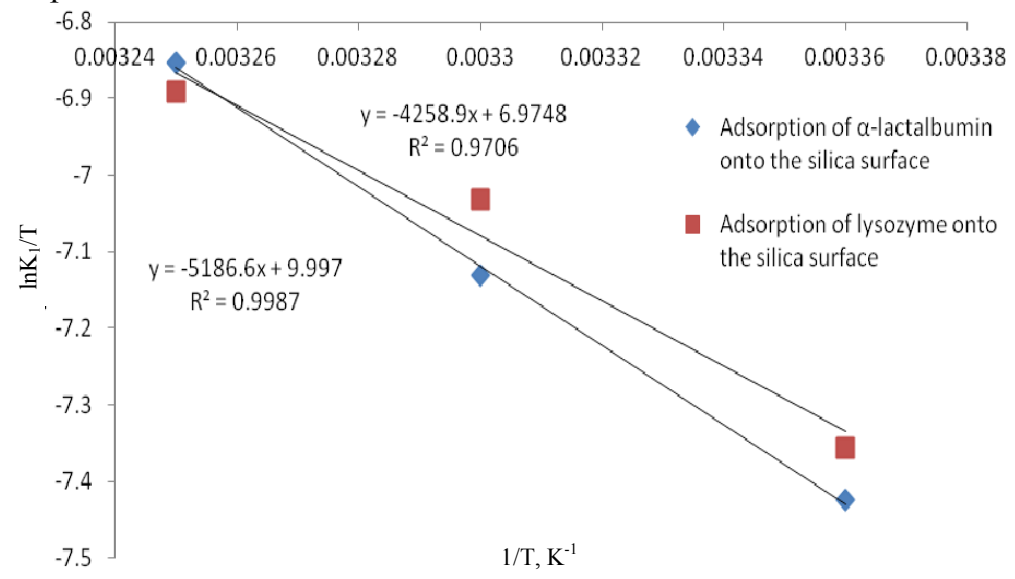

Figure 7. Plot of $\ln \mathrm{k}_{1}^{*} / \mathrm{T}$ against $\mathrm{T}^{-1}$ for the adsorption of the proteins onto the silica surface following Eyring Equation 


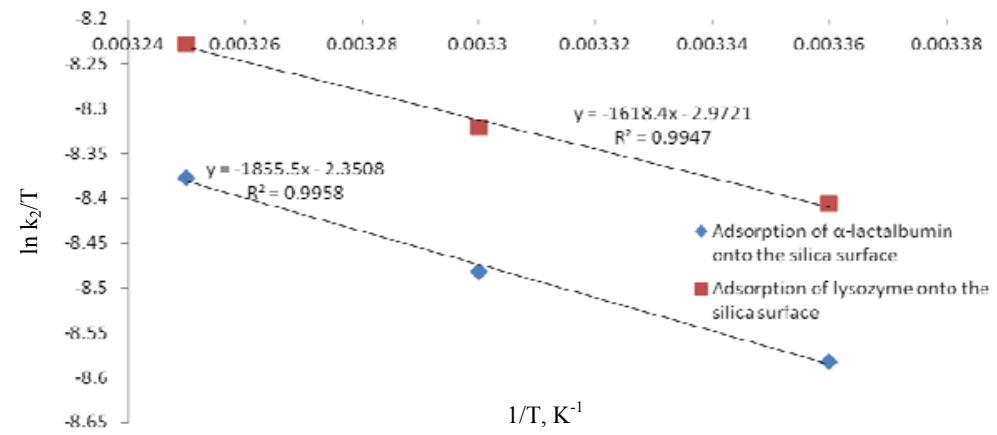

Figure 8. Plot of $\ln \mathrm{k}^{*}{ }_{2} / \mathrm{T}$ against $\mathrm{T}^{-1}$ for the adsorption of the proteins onto the silica surface following Eyring Equation

Table 1. Activation energy values for adsorption kinetics of $\alpha$-lactalbumin and lysozyme at silica - water interface, initial conc. $=1.0 \mathrm{mg} \mathrm{L}^{-1}$

\begin{tabular}{lll}
\hline (Parameter) & $\alpha$-Lactalbumin & Lysozyme \\
\cline { 2 - 3 } & Numerical values & Numerical values \\
\hline$\Delta \mathrm{E}_{1} *\left(\mathrm{~kJ} \mathrm{~mol}^{-1}\right)$ & 45.637 & 41.430 \\
$\Delta \mathrm{E}_{2}^{*}\left(\mathrm{~kJ} \mathrm{~mol}^{-1}\right)$ & 17.942 & 15.971 \\
$\Delta \mathrm{H}_{1} *\left(\mathrm{~kJ} \mathrm{~mol}^{-1}\right)$ & 43.121 & 38.836 \\
$\Delta \mathrm{H}_{2} *\left(\mathrm{~kJ} \mathrm{~mol}^{-1}\right)$ & 15.427 & 11.379 \\
$\Delta \mathrm{S}_{1} \times 10^{3}\left(\mathrm{~kJ} \mathrm{~mol}^{-1} \mathrm{~K}^{-1}\right)$ & -114.422 & -128.095 \\
$\Delta \mathrm{S}_{2} \times 10^{3}\left(\mathrm{~kJ} \mathrm{~mol}^{-1} \mathrm{~K}^{-1}\right)$ & -217.081 & -229.183 \\
\hline
\end{tabular}

\section{Conclusion}

This study indicates that silica could be used as an effective adsorbent material for the removal of $\alpha$-lactalbumin and lysozyme from aqueous solution. The adsorption of the proteins onto the silica surface was found to be time and temperature dependent. Adsorption process followed the first order kinetics with two kinetic rate constants $\mathrm{k}_{1}$ and $\mathrm{k}_{2}$ with $\mathrm{k}_{1}>\mathrm{k}_{2}$. Using the Arrhenius equation, the activation energies $\Delta \mathrm{E}_{1} *$ and $\Delta \mathrm{E}_{2} *$ were calculated. The relationship between $\Delta \mathrm{S}^{*}$ and $\Delta \mathrm{H}^{*}$ shows that $\mathrm{k}_{1}$ step is mostly an enthalpy-controlled process at the activated state while $\mathrm{k}_{2}$ step is mostly an entropy-controlled process at the activated state. $\Delta \mathrm{S}_{1}$ * and $\Delta \mathrm{S}_{2}{ }^{*}$ calculated from Eyring equation were both negative. This shows that refolding as well as unfolding of proteins at the interface is controlled mostly by the order-disorder parameter $\Delta \mathrm{S}^{*}$ occurring in the activated state of Eyring's equation. It can be concluded from the results that the adsorption of these proteins onto the silica surface involved two major steps. The first is the initial binding or anchorage of the protein molecules at the substrate. In this case, a certain fraction of the lysozyme and $\alpha$-lactalbumin molecules in the sub-phase possessing energy in excess of the energy of activation $\Delta \mathrm{E}_{1}{ }^{*}$ form complexes at the active sites on the silica surface. In the second step of the kinetic process, the segments of the polypeptide unit of these proteins not in contact with the underlined surface may begin to rearrange and when they come into proximity with similar segments of another adsorbed protein molecule may begin molecular reorganization or arrangement due to protein-protein interaction. Expansion by unfolding and the rearrangement and refolding of the polypeptide chains at the interface resulting from protein-protein interaction have been found in our study to be mostly entropy-controlled. Results generally show that $\alpha$-lactalbumin was slightly better adsorbed onto the silica surface as compared to the lysozyme. 


\section{References}

1. Ngadi N, Abrahamson J, Fee C and Morison K, Int J Biol Life Sci., 2009, 5, 106-110.

2. Xiaoyu W and Ganesan N, Biochimica et Biophysica Acta, 2008, 1784(11), 1694-1701.

3. Nezu T, Masuyama T, Sasaki K, Saitoh S, Taira M and Araki Y, Dent Mat J., 2008, 27(6), 573-580.

4. Omid M, Hamid M and Mehdi N, Iran Polym J., 2003, 12(6), 477-484.

5. Andrade J D, Hlady V and Wei A P, Pure Appl Chem., 1992, 64(11), 1777-1781.

6. Rovira-Bru M, Giralt F and Cohen Y, J Colloid Int Sci., 2001, 235(1), 70-79; DOI:10.1006/jcis.2000.7355

7. Walker D S, Garrison M D and Reichert W M, J Colloid Int Sci., 1993, 157(1), 41-49; DOI:10.1006/jcis.1993.1155

8. Chaiyasut C and Tsuda T, Chromatography, 2001, 22, 2.

9. Whalgren M C, Arnebrant T and Paulson M A, J Colloid Int Sci., 1993, 158(1), 46-53; DOI:10.1006/jcis.1993.1227

10. Horbett T A and Brash J L, Proteins at interfaces: Current Issues and future Prospects, Proteins at Interfaces: Physiochemical and Biochemical Studies, Brash J L and Horbett T A (Eds)., American Chemical Society, Washinton D.C. 1987, 1-33.

11. Noinville S, Revault M and Baron M H, Biopolymers, 2002, 67(4-5), 323-326; DOI:10.1002/bip.10117

12. Andrade J D, Principles of Protein Adsorption, Surface and Interfacial Aspects of Biomedical Polymers, Vol. 2, Andrade J D (Ed.), Plenum Press, New York, 1985.

13. Czeslik C and Winter R, J Phys Chem., 2001, 3, 235.

14. Gilles C H and Nakhwa S N, J Appl Chem., 1962, 12, 266.

15. Lowry O H, Rosebrough N J, Farr A L and Randall R S, J Biol Chem., 1951, 193, 265-275.

16. Lagergren S, Zur Theorie der Sogenanten Adsorption gelostn. Stoffe. Ak. Handl. Bihay, 1898, 24, 39.

17. Sarkar D and Chattoraj D K, J Colloid Int Sci., 1993, 157(1), 219-226; DOI:10.1006/jcis.1993.1179

18. Damodaran S and Song K B, Biochim Biophys Acta, 1988, 954, 253-264.

19. Atkins P and De Paula J, Atkins Physical Chemistry, $9^{\text {th }}$ Ed., W. H. Freeman and Company, 2010, p849. 